\title{
PCR detection of Bartonella spp. in the dog
}

\author{
Jarmila Konvalinová1, Vlasta Svobodová ${ }^{2}$, Dobromila Molinková ${ }^{3}$, Miroslav Svoboda ${ }^{1}$ \\ University of Veterinary and Pharmaceutical Sciences Brno, Faculty of Veterinary Medicine, \\ ${ }^{1}$ Small Animal Clinic, ${ }^{2}$ Department of Pathological Morphology and Parasitology, \\ ${ }^{3}$ Department of Infectious Diseases and Microbiology, Brno, Czech Republic
}

Received September 27, 2013

Accepted March 26, 2014

\begin{abstract}
Our study aimed at using PCR to identify the incidence of Bartonella spp. in blood of dogs. Altogether 286 dogs of 92 breeds aged 3 month to 17 years were tested from October 2008 to December 2009. Healthy dogs as well as dogs with various clinical symptoms of disease were included in the group. Samples were tested by polymerase chain reaction (PCR) specific for the presence of Bartonella spp. Following the DNA examination in 286 dogs by PCR and subsequent sequencing, two samples were identified as Bartonella henselae $(0.7 \%)$. Other species of Bartonella were not found. It was the first time in the Czech Republic when incidence of Bartonella spp. was determined in dogs.
\end{abstract}

Vector born disease, zoonosis, infection, PCR diagnostics, cat scratch disease, B. henselae

In the last two decades, more than twenty Bartonella species or subspecies have been described. At least eleven of them are considered as human pathogens (Boulouis et al. 2005; Maggi et al. 2012b). Out of these eleven, six were identified also in dogs and cats. Cats are a major reservoir of $B$. henselae, B. clarridgeiae, B. koehlerae, and B. bovis (Gurfield et al. 1997; Bermond et al. 2002). Dogs can be infected with $B$. vinsonii subsp. berkhoffi, B. henselae, B. clarridgeiae, B. washoensis, B. elizabethae, and B. quintana (Chomel et al. 2006; Beerlage et al. 2012).

In the last few years, new Bartonella species have been isolated also from many wild rodents and ruminants. Some recent studies indicate that these new species could be responsible for certain human and canine infections (Boulouis et al. 2005; Maggi et al. 2012a).

In general, Bartonella bacteria induce none or only mild clinical signs in the natural hosts. However, infection of other than natural, i.e. accidental host can result in a serious or life-threatening disease.

In humans, this bacterium causes the so-called cat scratch disease (CSD) which is spread worldwide. In children, this infection is a relatively common cause of fever of unknown origin (Carithers 1985; Boulouis et al. 2005). In immunocompromised patients this infection has a serious or even fatal course.

Bartonella was first isolated in dogs in 1993 (Breitschwerdt et al. 1995). Ticks were identified as the bartonellosis vector in dogs; in Europe the most prominent are I. ricinus (Billeter et al. 2008; Cotté et al. 2008). The most important in dogs is Bartonella vinsonii subsp. berkhoffii. It has been proven that this species plays an important role in cases of endocarditis in dogs and humans (Breitschwerdt et al. 1999). Dogs can be further infected with $B$. henselae, B. clarridgeiae B. washoensis B. elizabethae, and B. quintana (Mexas et al. 2002; Chomel et al. 2006; Saunders and Monroe 2006; Morales et al. 2007; Diniz et al. 2009).

Address for correspondence:

Jarmila Konvalinová

Small Animal Clinic

Faculty of Veterinary Medicine, UVPS Brno

Palackého tř. 1/3, 61242 Brno, Czech Republic

Phone: +420 541562375

E-mail: konvalinovaj@vfu.cz

http://actavet.vfu.cz/ 
There is not enough information about bartonellosis in dogs in various countries. The incidence is higher in warmer climates. There are several studies on seroprevalence of Bartonella antibodies in dogs, however, none of these studies reported the detection of DNA of individual Bartonella species in dogs (Guptill 2003; Solano-Gallego et al. 2004; Boulouis et al. 2005; Parpaglia et al. 2007; Yabsley et al. 2008). In this study we therefore determined the incidence of Bartonella spp. in dogs by PCR.

\title{
Materials and Methods
}

\begin{abstract}
Altogether 286 dogs of 92 breeds were tested from October 2008 to December 2009. The examined dogs were patients of the Small Animal Clinic coming from Brno and the South Moravian Region of the Czech Republic. Crossbreeds prevailed $(n=35)$ followed by Dachshunds $(n=31)$ and German Shepherds $(n=15)$. The group included 124 females, of these 39 neutered; and 162 males, of these 12 castrated. The age of the animals ranged from 3 months to 17 years (mean 6.5 year). Their weight varied from 2 to $62 \mathrm{~kg}$. A total of 51 healthy dogs plus 235 dogs with various clinical symptoms of disease were included in the group. Standard haematological and biochemical blood tests were carried out for most of the dogs. Blood was collected from v. cephalica antebrachii or v. jugularis. From each dog we obtained samples of whole blood. Samples were stored at $-18{ }^{\circ} \mathrm{C}$ until testing.

Whole blood samples were tested by PCR. DNA was extracted from samples using the commercial QIAGEN NucleoSpin Blood kit (Machery-Nagel, Germany). DNA samples were tested with the use of primers: forward 5'-(C/T)CTTCGTTTCTCTTTCTTCA-3' and reverse 5'-AACCAACTGAGCTACAAGCC-3' according to Jensen et al. (2000). The estimated size of the final product in the case of $B$. henselae was $172 \mathrm{bp}, B$. clarridgeiae $154 \mathrm{bp}$, B. elizabethae $241 \mathrm{bp}$, B. quintana $157 \mathrm{bp}$, and B. vinsonii subsp. berkhoffii $260 \mathrm{bp}$. As positive control we used the DNA of $B$. henselae. The PCR reaction was carried out in a total amount of $20 \mu 1$, using $2 \mu 1$ of DNA, $10 \mu \mathrm{l}$ of Combi PPP Master Mix (Top-Bio), $0.1 \mu \mathrm{l}$ of each primer diluted to $100 \mathrm{pmol} / \mu 1$ and $7.8 \mu 1$ PCR water. Biometra T Personal Thermocycler (Whatman Biometra, Göttingen, Germany) was used for the reaction. The PCR product was visualized by ethidium bromide and 3\% agarose gel (70 ml TAE, $2.1 \mathrm{~g}$ agarose, $3 \mu 1$ ethidium bromide - stock solution $10 \mathrm{mg} / \mathrm{ml}$ in PCR water) at the voltage of $120 \mathrm{~V}$. The electrophoresis was carried out using the Standard Power Pack P25T and horizontal electrophoresis by Cleaver Scientific Ltd. Transilluminator Vilber Lourmat (Deutschland $\mathrm{GmbH}$, Germany) was used for visualisation.

PCR products from positive samples were purified from the agarose gel using QIAquick Gel Extraction kit (Qiagen, Machery-Nagel, Germany) and then subjected to sequencing (Macrogen, Seoul, Korea).
\end{abstract}

\section{Results}

Following the DNA examination in 286 patients by PCR and subsequent sequencing, two samples were identified as Bartonella henselae $(0.7 \%)$. Other species of Bartonella were not found.

\section{The first positive dog}

Eight-year-old neutered female Poodle weighing $7 \mathrm{~kg}$ was presented at the clinic with signs of lethargy and loss of appetite. The clinical examination revealed slight enlargement of the mandibular and superficial cervical lymph nodes, and a body temperature of $39.6{ }^{\circ} \mathrm{C}$. A blood sample was collected in December 2008. Haematological examination revealed mild thrombocytopenia $\left(183 \times 10^{9} / 1\right)$; other basic haematological and biochemical indicators were within the physiological range.

The second positive dog

It was a 2-year-old Border Collie dog weighing $21 \mathrm{~kg}$. The dog showed no clinical signs of disease. It was brought for a preventive check. A blood sample was collected in March 2009. Haematological examination revealed only lymphopaenia $\left(0.783 \times 10^{9} / 1\right)$ and slightly elevated ALT activity (1.69 $\mu \mathrm{kat} / \mathrm{l})$; other indicators were within the physiological range.

\section{Discussion}

Bartonella has a potential to cause serious disease in humans as well as in a wide range of domestic and wild animals. Cats are usually without clinical symptoms or they are only 
nonspecific. But they are important reservoirs of $B$. henselae causing the cat scratch disease (CSD). Dogs are considered to be the reservoir of $B$. vinsonii subsp. berkhoffii. It has been demonstrated, however, that they can be infected with other species including Bartonella henselae (Mexas et al. 2002; Chomel et al. 2006; Saunders and Monroe 2006; Morales et al. 2007; Diniz et al. 2009). Bartonella henselae has been described in a number of cases of dog diseases (Guptill 2003). These were mostly chronic diseases characterized by apathy, loss of appetite, weight loss, exercise reluctance, ataxia, lymphadenopathy and other, often nonspecific symptoms. Blood is usually tested for thrombocytopaenia. Surprisingly enough, in our group we detected $B$. henselae only in two dogs $(0.7 \%)$. Our first patient had symptoms corresponding to those of bartonellosis (lethargy, loss of appetite, lymphadenopathy) at the time of examination and the thrombocytopenia finding was appropriate. However, the described clinical and laboratory results may be identical in other infections and diseases and this is why $B$. henselae cannot be identified as the causative agent. The second positive dog was brought to the clinic for preventive check showing no signs of disease.

Bartonellas are transmitted by vectors. In case of cats the vectors are fleas, in particular cat fleas (Ctenocephalides felis), ticks and other blood-sucking insects. Ticks were identified as the vector in dogs. The most important tick in Europe is Ixodes ricinus described in the study by Cotté et al. (2008) as a competent vector for B. henselae. Transmission is possible even through the saliva in dog bites. People can be infected by ticks, cat and dog scratches or bites (Boulouis et al. 2005; Podsiadly et al. 2007; Billeter et al. 2008; Maggi et al. 2012a).

By PCR testing of whole blood we established the presence of $B$. henselae in two dogs $(0.7 \%)$. A Polish study by Podsiadly et al. (2007) reports that they examined 54 dogs for Bartonella spp. DNA in the blood. DNA was not identified in a single case but they detected the presence of specific IgG antibodies against $B$. henselae in $50 \%$ of tested dogs. Many authors state that if Bartonella DNA is detected in an organism, the serology is negative (Duncan et al. 2007; Morales et al. 2007; Duncan et al. 2008; Cherry et al. 2009; Diniz et al. 2009).

Even though dogs are natural hosts of $B$. vinsonii subsp. berkhoffii, in our study we detected only the presence of $B$. henselae. However, this is a serious zoonotic agent and our results show the necessity to consider dogs as a potential source of human infection. The prevention of bartonellosis generally lies in the protection of animals against flea and tick infestation. It is therefore advisable to treat animals with antiparasitics on a regular basis, either in the form of spray, spot on drugs or collars.

\section{References}

Beerlage Ch, Varanat M, Linder K, Maggi RG, Cooley J, Kempf VAJ, Breitschwerdt EB 2012 : Bartonella vinsonii subsp. berkhoffii and Bartonella henselae as potential causes of proliferative vascular diseases in animal. Med Microbiol Immunol 201: 319-326

Bermond D, Boulouis HJ, Heller R, Van Laere G, Monteil H, Chomel BB, Sander A, Christoph D, Piémont Y 2002: Bartonella bovis Bermond et al. sp. nov. and Bartonella capreoli sp. nov., isolated from European ruminants. Int J Syst Evol Microbiol 52: 383-390

Billeter SA, Levy MG, Breitschwerdt EB 2008: Vector transmission of Bartonella species with emphasis on the potential for tick transmission. Med Vet Entomol 22: 1-15

Boulouis HJ, Chang CC, Henn JB, Kasten RW, Chomel BB 2005: Factors associated with the rapid emergence of zoonotic Bartonella infections. Vet Res 36: 383-410

Breitschwerdt EB, Kordick DL, Malarkey DE, Keene B, Hadfield TL, Wilson K 1995: Endocarditis in a dog due to infection with a novel Bartonella subspecies. J Clin Microbiol 33: 154-160

Carithers HA 1985: Cat-scratch disease: an overview based on a study of 1,200 patients. Am J Dis Child 139: 1124-113

Cherry NA, Diniz PPVP, Maggi RG, Hummel JB, Hardie EM, Behrend EN, Rozanski E, DeFrancesco TC, Cadenas MB, Breitschwerdt EB 2009: Isolation or molecular detection of Bartonella henselae and Bartonella vinsonii subsp. berkhoffii from dogs with idiopathic cavitary effusions. J Vet Intern Med 23: 186-189 
Chomel BB, Boulouis HJ, Maruyama S, Breitschwerdt EB 2006: Bartonella spp. in pets and effect on human health. Emerg Infect Dis 12: 389-394

Cotté V, Bonnet S, Le Rhun D, Le Naour E, Chauvin A, Boulouis HJ, Lecuelle B, Lilin T, Vayssier-Taussat M 2008: Transmission of Bartonella henselae by Ixodes ricinus. Emerg Infect Dis 14: 1074-1080

Diniz PPVP, Wood M, Maggi RG, Sontakke S, Stepnik M, Breitschwerdt EB 2009: Co-isolation of Bartonella henselae and Bartonella vinsonii subsp. berkhoffi from blood, joint and subcutaneous seroma fluids from two naturally infected dogs. Vet Microbiol 138: 368-372

Duncan AW, Maggi RG, Breitschwerdt EB 2007: Bartonella DNA in dog saliva. Emerg Infect Dis 13: 1948-1950

Duncan AW, Marr HS, Birkenheuer AJ, Maggi RG, Williams LE, Correa MT, Breitschwerdt EB 2008: Bartonella DNA in the blood and lymph nodes of golden retrievers with lymphoma and in healthy controls. J Vet Intern Med 22: 89-95

Guptill L 2003: Bartonellosis. Vet Clin Small Anim 33: 809-825

Gurfield AN, Boulouis HJ, Chomel BB, Heller R, Kasten RW, Yamamoto K, Piemont Y 1997: Coinfection with Bartonella clarridgeiae and Bartonella henselae and with different Bartonella henselae strains in domestic cats. J Clin Microbiol 35: 2120-2123

Jensen WA, Fall MZ, Rooney J, Kordick DL, Breitschwerdt EB 2000: Rapid identification and differentiation of Bartonella species using a single-step PCR assay. J Clin Microbiol 38: 1717-1722

Maggi RG, Mascarelli PE, Havenga LN, Naidoo V, Breitschwerdt EB 2012a: Co-infection with Anaplasma platys, Bartonella henselae and Candidatus Mycoplasma haematoparvum in a veterinarian. Parasites \& Vectors 6: 103

Maggi RG, Mozayeni BR, Pultorak EL, Hegarty BC, Bradley JM, Correa M, Breitschwerdt EB 2012b: Bartonella spp. bacteremia and rheumatic symptoms in patients from Lyme disease-endemic region. Emerg Infect Dis 18: 783-791

Mexas AM, Hancock SI, Breitschwerdt EB 2002: Bartonella henselae and Bartonella elizabethae as potential canine pathogens. J Clin Microbiol 40: 4670-4674

Morales SC, Breitschwerdt EB, Washabau RJ, Matise I, Maggi RG, Duncan AW 2007: Detection of Bartonella henselae DNA in two dogs with pyogranulomatous lymphadenitis. JAVMA 230: 681-685

Parpaglia MLP, Masu G, Masala G, Porcu R, Zobba R, Pintori G, Cocco R 2007: Seroprevalence of Bartonella henselae in dogs and cats in Sassari. Vet Res Commun 31 317-320

Podsiadly E, Chmielewski T, Marczak R, Sochon E, Tylewska-Wierzbanowska S 2007: Bartonella henselae in the human environment in Poland. Scand J Infect Dis 39: 956-962

Saunders GK, Monroe WE 2006: Systemic granulomatous disease and sialometaplasia in a dog with Bartonella infection. Vet Pathol 43: 391-392

Solano-Gallego L, Bradley J, Hegarty B, Sigmon B, Breitschwerdt EB 2004: Bartonella hensleae IgG antibodies are prevalent in dogs from southeastern USA. Vet Res 35: 585-595

Yabsley MJ, Mc Kibben J, Macpherson CN, Cattan PF, Cherry NA, Hegarty BC, Breitschwerdt EB, O Connor T, Chandrashekar R, Paterson T, Perea ML, Ball G, Friesen S, Goedde J, Henderson B, Sylvester W 2008: Prevalence of Ehrlichia canis, Anaplasma platys, Babesia canis, Hepatozoon canis, Bartonella vinsonii berkhoffii, and Rickettsia spp. in dogs from Grenada. Vet Parasitol 151: 279-285 